The 'East Is Red' Goes Pop: Commodification, Hybridity and Nationalism in Chinese Popular Song and Its Televisual Performance

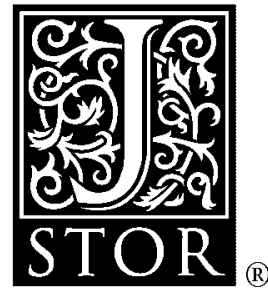

\author{
Gregory Lee
}

Popular Music, Vol. 14, No. 1. (Jan., 1995), pp. 95-110.

Stable URL:

http://links.jstor.org/sici?sici=0261-1430\%28199501\%2914\%3A1\%3C95\%3AT\%27IRGP\%3E2.0.CO\%3B2-E

Popular Music is currently published by Cambridge University Press.

Your use of the JSTOR archive indicates your acceptance of JSTOR's Terms and Conditions of Use, available at http://www.jstor.org/about/terms.html. JSTOR's Terms and Conditions of Use provides, in part, that unless you have obtained prior permission, you may not download an entire issue of a journal or multiple copies of articles, and you may use content in the JSTOR archive only for your personal, non-commercial use.

Please contact the publisher regarding any further use of this work. Publisher contact information may be obtained at http://www.jstor.org/journals/cup.html.

Each copy of any part of a JSTOR transmission must contain the same copyright notice that appears on the screen or printed page of such transmission.

JSTOR is an independent not-for-profit organization dedicated to creating and preserving a digital archive of scholarly journals. For more information regarding JSTOR, please contact support@jstor.org. 


\title{
The 'East is red' goes pop: commodification, hybridity and nationalism in Chinese popular song and its televisual performance
}

\author{
GREGORY LEE
}

In 1989 the Western media left its consumers with the romantic impression that it was merely the students who were demonstrating for 'democracy', as if emulating the student demonstrations of twenty years before in Europe and America. But there were workers involved too, who had illegally organised unofficial labour unions, and beyond concerns about democratic rights, there was the impetus of a socio-economic crisis. Most of those killed by the tanks in Tiananmen were workers, not students. People from all walks of life had marched and demonstrated throughout China from Canton ti Lhasa. Nine months before the Tiananmen massacre of June 1989, reversals in official economic policy put a halt to investment and constructions, and the problem of unemployment of rural migrants who had come to the towns was exacerbated. This migration was illegal but had been tolerated since labour was needed for construction. In 1989 anywhere between 60 to 100 million unemployed and homeless people were moving around the country en masse. At one time 250,000 were camped at Canton railway station.

Today China is suffering more and more from social and economic problems that once were only associated with traditional capitalist economies, and whenever there are social problems in China, in absolute terms of human victims, they assume enormous proportions. When the People's Republic of China was established in 1949, China had a population of 400 million. Now China has a population of 1,400 million, over three times the population of forty years ago. The West's media has publicised and lauded the Chinese leadership's conversion to capitalism, but less is heard of the problems of a market economy that came with the new capitalism. The 1980 s reforms in the countryside, where 80 per cent of China's population lives, at first brought a degree of prosperity to a minority of peasants who lived near market towns. But new economic priorities have reversed the countryside's fortunes, and near the big cities much farming land is succumbing to urban sprawl. Huge numbers of peasants are unemployed or underemployed, and rural labour is not taken into account in official statistics and policy. Surplus farm labour has exceeded 200 million, and by the next century there are likely to be over 300 million unemployed in China's countryside; a number of people 
greater than the population of the USA and Canada together. More than 60 per cent of China's rural labour force is functionally illiterate. More than 50 per cent of women did not attend school. Once the rural unemployed come to the cities in search of jobs and the consumer lifestyle, most of them stay unemployed and effectively homeless. Thousands of people every night bed down on the sidewalks in major Chinese cities, infants beg on the streets and harass passers-by in scenes reminiscent of the 1940s; the like of which I had only previously seen in films made by communist producers to expose the social evils of the old China. Enormous gulfs are opening up between the prosperous and the poverty-stricken. The fact is that in China it is not just the human rights of the various freedoms of expression that are often curtailed but also the basic rights to a home and a livelihood. The Communist Party presented itself as the party of the people, in particular the party of the peasants whose support brought it to power forty years ago, but it has failed that very constituency in its current blind striving for economic modernisation. This is the (often hidden) context of today's cultural production and consumption in the urban China, largely constituted by China's long coastline and the immediate hinterland which comprises around 300 million consumers.

For over a century of reform and revolution artists and intellectuals have sought to speak for those with no voice. During the Cultural Revolution of 196676 a generation of urban youth were 'sent down', as the expression went, to learn from the peasants in the countryside. Many of them were idealistic and fervent supporters of Chairman Mao. They were sorely disillusioned by the poverty and spartan existence which was at odds with the Maoist illusion they had been reared on. Perhaps the greatest tragedy was the loss of their idealism. They ceased to have faith in the revolution. It is from this generation that the poets and film-makers of the post-Mao late 1970s and 1980s come. The poet Bei Dao (1949) is commonly seen as the cultural oppositional voice of that time and his poem 'The Answer' as the representative cry of his generation. The words he himself declaimed at the first Tiananmen Incident in 1976, after the death of the relatively liberal premier, Zhou Enlai, were subsequently appropriated and redeployed by the 1989 occupants of Tiananmen Square:

\author{
Let me tell you world \\ I-do-not-believe \\ I don't believe the sky is blue \\ I don't believe in thunder's echoes \\ I don't believe that death knows no revenge
}

In the 1990s a generation which hardly knew the Cultural Revolution, but only the China of market reforms and the China of Tiananmen, is not so much concerned with the past but the future. They are represented and entertained not by the poet as such, but by the pop singer.

\title{
I
}

Popular music as a modern medium, recorded and transmitted by mechanical and electronic means, has had almost as much of an impact in Asia as it has in the West and in other societies where the technology of recording and diffusion has been available. Already in 1930s semi-colonial China there was a burgeoning recorded popular music industry. Now at the end of the twentieth century, as the 
West's music industry falters together with the rest of the capitalist manufacturing industries in the face of continuing Western capitalist decline, the hopes and fortunes of the recording business are pinned on the continued expansion of the market for popular music and music videos in Asia, especially in East Asia; 'except in the Asia-Pacific Region, the rest of the world's music market is declining', according to record industry executive Cheung Man-sun. ${ }^{1}$

Some of the questions I hope to raise here are: can music have different functions in Asia or will it be used in ways similar to its use in the West? Will there be space, for instance, in the production and consumption of popular music in capitalist China, for the kind of critique that other popular music traditions have afforded? Will the practices of Chinese popular music be able to recuperate and develop 'nativist' elements and will such developments in any case render popular music any more progressive or 'correct'? What is the nature of alternative voices or, even more ambitiously, strategies within the practices of popular music?

While not yet an advanced consumer society, China is embarking on a capitalist spree of heroic consumption. It is now among the ten largest economies in the world, and predicted to be the largest early in the next century.

Whether or not popular music has a future as a truly popular, or rather people's music, recuperated by and produced by those who are now consumers, as Jacques Attali somewhat idealistically foresees in the 'Composition' section of his 1977 work Bruits (Noises) (and in this context the global phenomenon of the karaoke machine may be merely a cruel parody of such a vision), it may still be too early to say. But the question of whether popular music is as irredeemable as Adorno (in his perceptive, enlightening, but ultimately elitist, essay 'On popular music', now fifty years old) would have us believe can now be addressed. ${ }^{2}$

\section{II}

There are, of course, different categories of popular music, even within that which seeks to be 'hit' music. There is, for example, the consciously political: songs, music and performance (visually recorded for distribution or not) which have a clear political agenda and message(s). In the Chinese (in its widest sense) context, there are, for instance, the lyrics of the Taiwanese, Hong Kong-based Luo Dayou which contain important messages in themselves. The popular and commercially successful mainland singer Cui Jian's message is conveyed not merely by sound, but also by a subversive and ironically deployed semiotics of visual image (the now celebrated red blindfold and People's Liberation Army green jacket). But even the enunciation of the lyrics (characterised by a coarseness and self-conscious use of street-wise accent) and the near grammatically incoherent lyrics themselves, challenge the tame lyrical practices of official Chinese popular music production, and join the music in the production of a kind of emotion that, 'beyond words', disrupts the official order. (Chow 1991, p. 135).

Then there is what could be called the unconsciously political. The majority of hit songs are those promoted by the music industry purely and simply as commodities; which is not to say that the category of 'political' songs/music and singers/musicians may not be so promoted. Yet, this second category of popular music can also effect, or retard, political change by bringing about changes in the ideological environment, or maintaining an ideological stasis. 
I shall first deal with seemingly 'unpolitical' commercial hit music. In China at the present time, there are two major types of popular music. The officially sanctioned and promoted ballad-type music sung usually by solo artists, but also occasionally by choirs, is called tongsu or common music. The officially discouraged popular music performed by unofficial rock groups whose style ranges from troubadour-type pop to heavy metal, is known simply as liuxing yinyue or popular music.

In thinking about the function that the music producers perform, I have found it helpful to allude to the concept of bardic television developed by Fiske and Hartley (1978) who have proposed that the social function of television is akin to the mediating function of the bards in Celtic societies. ${ }^{3}$ Like the bards, the medium of television stands between the ruling class, who pay and license the television, and the rest of society whose speech and events are processed by the television into a specialised, rhetorical language which is then played back to the society. This mediating role is active and implies that neither the ideology of the owners/rulers nor the experience of viewers/consumers is merely reflected, rather theirs is a mediated, processed 'reality', an artificial construct, arrived at by the investment of much ideological labour. Of course, while much television production is meant to 'make sense' of the world, lyrics are often perceived as mere distraction. However, there is something of this mediating, bardic function discernible in the contemporary practices of popular music, as one would expect of a music industry so firmly and increasingly enmeshed in the electronic and broadcast media.

It is a sort of bardic function that Antoine Hennion describes when he writes of French pop music producers seeking and reproducing 'infra-linguistic categories', the 'socio-sentimental' (1983, p. 160). For as with the television message we are 'at once celebrated and implicated' in the message of the popular hit-songs, in the ideologically structured 'socio-sentimental' (re)produced by the bardic music producers (O'Sullivan et al. 1983, p. 19). ${ }^{3}$ Hennion, however, emphatically subscribes to the view that the industry is simply responsive to the consumers' wants, 'Pop songs do not create their public, they discover it'. Furthermore, Hennion is critical of the opposition which stresses the arbitrary imposition of meanings by producers and sellers' in which the public is seen 'as passive, ready to absorb whatever it is presented with', a vision which, according to Hennion, 'overlooks the active use to which people put pop music, the imaginary existence they lead through it, which is not reducible to the official social hierarchies' (1983, p. 191).

In the modern Chinese context, while some of Hennion's argument, developed in relation to the French pop music industry, remains valid as far as the 'active use' to which people put pop music is concerned, the 'imposition of meaning' in Chinese popular music, whether official or unofficial, is as I shall seek to demonstrate, far from arbitrary.

In China, the dissemination of popular music resembles more the unidirectional nature of media flow whether via domestic channels, or through international satellite television, ${ }^{4}$ such as the Hong Kong-based Star TV. To what extent can even the consumer 'choice' provided by MTV pretend to reverse the unidirectional nature of such broadcasting? Moreover, in the case of Asian MTV which transmits substantially the same European-American MTV product as in the Anglophone West, the hegemony of this uni-directional flow is reinforced.

It should come as no surprise in this late capitalist era that that icon of global culture, Madonna, has been consumed in China as elsewhere. In India, indeed, there is the Madonna look-alike and sound-alike, the self-styled 'Hindi Madonna', 
Alisha. China, however, like much of the consumerist world is still fixated on the 'authentic' Madonna. In China, where publishing is still largely in the hands of government and censorship can be sporadically severe, the official use of Madonna is pragmatic. For instance, visual representations of Madonna are employed on book and magazine covers to sell song books published by government publishing houses which under Deng Xiaoping's market economics are instructed to both make money and maintain the ideological line. One particular song book sports on the front cover a bare midrifted Madonna, framed by lesser stars of the AngloSaxon world of 1980s (Kylie Minogue, Rick Astley, Bros and Tanita Tikaram). The back cover shows a sensuous Madonna, head thrown back, set against a voluptuous velvet red background. Inside the package are English and Chinese versions of songs such as the 1960s Beatles hit 'Hey Jude', 'The Green, Green Grass of Home' credited to Joan Baez, 'Amazing Grace', and a medley of 1907s and 1980s mainstream hits by Michael Jackson and Lionel Ritchie. There does not happen to be a song by Madonna in the book, nor by any of the others who adorn the cover. What price a sign?

The lack of Madonna in the song book is echoed in an issue of the official mass circulation music magazine, Yinyue shenghuo (Music life), by which Madonna is multiply featured as a cover girl to help sell the product. Yet the promise of the cover is rewarded with not one article, photograph or song to do with Madonna. Instead what one finds are a selection of nationalistic and party songs such as 'Hail Tomorrow's Sun', 'Love the Motherland', 'The Love of the Coalminer', 'China, Sun of the New Age', 'China, You're On Your Way to Great Heights', 'New Great Wall, New Sun', and 'Oh Party Forever Youthful Mother', together with translations of one-time Western hits like 'Love is a Many Splendoured Thing' and 'How Much is That Doggie in the Window'. The image of Madonna in China as elsewhere is perhaps more significant than her sound.

The classic Maoist revolutionary songs dating back to the Yan'an guerilla-base days of the 1930s and 1940s have recently been making a comeback. Such consumption perhaps is in part due to a certain nostalgia for simpler, pre-consumerist and more idealistic times, parallel to the display of Mao badges and posters by drivers and others as good luck charms. But that same nostalgia had been previously deployed by subversive rock stars such as Cui Jian, and the irony of capitalist Western musical interpretation of Maoist songs perhaps reached its height with the $R \& B$ and reggae cover versions by Beijing Reggae, a group put together by a Chinese-American producer.

Official Chinese producers have been quick to exploit the trend, in order to make profit and perhaps political capital from it. So on the street stalls in China's cities one finds disco and other re-styled versions of Maoist classics. Unlike the Madonna offerings, if Mao is on the cover, Mao is what you get, even if the song books - on sale right next to the one featuring Madonna I mentioned above feature a Mao Zedong encircled by an array of his heavily made-up contemporary tongsu interpreters clad in white tuxedos and sequined ballroom gowns. In the bookstall, Mao is on sale right next to Madonna too, and on the music cassette street stalls right next to a subversively dressed Cui Jian. In late twentieth-century capitalist China, the market has established a consumerist and mythic equivalency between Mao and Madonna and Cui Jian.

Hennion's narrative of the relationship of consumer and music industry looks to the social use of music, and its role in aiding people to 'get through the day'. But apart from making profits for the music industry, is this not exactly what 
official society wants? Capitalism and dominant interests, whether in China or the USA, have no economic need to distinguish between high and popular culture. Moreover, if popular music can provide additional tools of suppression, over and above economic mechanisms, by culturally reproducing existent social formations and thus neutralise or appropriate future practices of society so as to perpetuate existing power relations, then the industry provides additional value in sustaining dominant interests. The Chinese regnant authority's licensing of the distribution and performance of King Kong pop music in China, together with its own distribution of revolutionary songs refashioned as pop music, is just such an attempt to exploit popular culture by naturalising and legitimating the social authority of dominant, and in this context distinct but not necessarily conflicting, interests.

While Chinese producers may be providing dreams, both public and private, as Hennion claims French producers do, are they really 'feeling the pulse', to benevolently provide what the audience desires? Are they not rather, as Jacques Attali has suggested, concerned with the production not of the product, but of 'demand'? For as Attali has observed, 'everywhere music is present, there also is money' (1977, p. 12). In China, as in the West, the concern of the producers of music is the production of both demand and thus money, and of ideology.

Attali has identified three other uses that a regnant authority has for music which seem particularly appropriate to the modern Chinese context: 'Faire Oublier, Faire Croire, Faire Taire'. And in the three cases - making people forget, making people believe, and silencing people - music is 'a tool of power: ritual, in the case of having people forget fear and violence; representative, in the case of having them believe in order and harmony; bureaucratic, in the case of having them believe in order and harmony; bureaucratic, in the case of silencing those who contest' (ibid., p. 36). The dream-world constructed out of pop music which is described by Hennion, resembles Attali's category of 'having forget', if not in this context 'having believe' and 'having silenced'.

Attali's discussion of the use and power of music is particularly pertinent to authoritarian states, to the Chinese context and to the Soviet, East German, Chilean, Brazilian or South African contexts at different moments over the last half-century:

[The theoreticians of totalitarianism] have all, without distinction, explained that it was necessary to forbid subversive noise, because they announce demands of cultural autonomy, claims of differences or of marginality: the anxiety of maintaining tonalism, the primacy of melody, distrust of new languages, codes, and instruments, the refusal of the abnormal is found in all these regimes. These are explicit translations of the political importance of cultural repression and control of noise. For Zhdanov . . . music, as an instrument of political pressure, had to be quiet, reassuring, calm. (ibid., p. 17-18)

Reassuring and calm, because 'noise', Attali tells us, 'is violence: it disturbs'. But the fact that noise disturbs means that it can disrupt the dominant order, its subversive potential is thus ever present. 'To make noise, is to interrupt a transmission, unplug, kill. It is a substitute for murder' (ibid., p. 47). Recent and extreme examples of the use of musical noise as such a simulacrum would be the deployment of classical music as a weapon in the filmic representation of the war in Vietnam Apocalypse Now, and the 'real life' invasion of Panama during which Noriega's residence was blasted by US forces with heavy metal music. The bombardment with noise of the besieged sect in Waco, Texas, in 1993 also vividly illustrates how the authorities have grasped very directly the disruptive effect of broadcast 
noise. In the Chinese context, before the availability of the technology of amplification, there is a long tradition of the political and martial deployment of noise especially that which evokes patriotic sentiment. For instance, The Story of Hua Guan Suo tells how Liu Bang an aspirant to the imperial throne in the third century $\mathrm{BC}$ employed the strategy of blasting his enemy, the King of Chu's troops with songs from their native state 'His eight thousand troops scattered amid the sounds of the songs of Chu' (1989, p. 33).

\section{III}

'Totalitarian' or not, and no matter which mode of production a state deploys in its project of modernisation, dominant classes and opposition movements alike have used music to sell nationalist sentiment, and similarly have used nationalist sentiment to sell music. ${ }^{6}$

The exploitation of patriotic sentiment occurs in various guises and for seemingly different ends; for example, to promote a certain political project, or to extract profit from people's nationalist ideology, sometimes both at once. Recently, some cultural producers in China have indulged in what seems like an ironic redeployment of nationalist rhetoric and semiotics; the Chinese group Hei Bao (Panther), a Hong Kong-Taiwan managed and marketed group, have done this in song and through music video for profit and career advancement, while Cui Jian's recuperation of Party-State signifiers (red kerchief, People's Liberation Army uniform, recycled revolutionary lyrics) both ironically and perhaps also in an attempt to recover a lost idealism, is part of a political project: his 'New Long March of Rock and Roll', which appropriates the mythic communist guerilla bid for survival of the 1930s, and which became a monumental national metaphor for revolutionary courage and idealism in the New China. But even Hei Bao, with an ambition seemingly limited to professional advancement and profit-making, defy official society and occupy national space in a subversive way. Their critique may seem more superficial than that of Cui Jian, and yet in its moment is no less damaging to the regnant authority. Hei Bao's violence is not solely, perhaps not mainly, channelled through their music and lyrics, but rather into their video image. The pictures show the group (self-as-commodity) in settings such as the Great Wall, the capital's main throughfare Chang'an Avenue, the Forbidden City, all national, almost sacred, spaces. Also a traffic cop podium is appropriated, a policeman argued with. In a way these acts of defiance against the patriarchal regnant authority and its central spaces, are similar to the message projected in the early 1980s British MTV videos analysed by E. Ann Kaplan, 'the anti-parental, anti-authority videos, revealing adolescent disillusionment with, and distaste for, parental, workrelated, or state authority' (1987, p. 67). Then there is the mimicry of Western popular music lore, most notably when the scene depicted on The Beatles' Abbey Road album cover, The Beatles walking across the zebra crossing, is re-enacted. This is surely a form of allusion which will be understood neither by the officials of official society, nor by the popular audience. So for whom and for what are the visual references to Western popular music mythology? At the time of Abbey Road, mainland Chinese people were chanting Maoist slogans in Tiananmen Square. It is true, of course, that the video was made mainly for consumption beyond the mainland, in Hong Kong, Taiwan and so on, but nevertheless it will have, like many other MTV videos, been seen in mainland China. 
It is the recuperation of national symbols and spaces which is of major interest. These symbols, ideological and mythical constructs - whether the Great Wall, or the Long March - are implicated not just with the construction of the nation but also with the construction and entrenchment of the Chinese Communist Party. The recuperation of those symbols also entails recuperating or challenging the idealism of nationalism/communism. What else can be meant by Cui Jian's 'new long march'? There is irony but also a recuperation of an originary, popular nationalism which not only grips high cultural intellectuals but also popular cultural heroes. How more 'Chinese' - at least in modern terms - could one get than Cui Jian's naive nationalism? Cui Jian's trumpet is emblematic of the Party-State's dilemma in condemning that which is 'polluted' by the West. For when sanctioned by the state, the instrument itself becomes as 'official' as can be. Cui Jian himself used to play trumpet for a state-run orchestra. When the instrument is played 'officially', it is legitimated, authenticated, and Chinese; used for the state it becomes an instrument of the state. But when it is used against the stage, when Cui Jian extracts from it defiant notes in his subversive performances, it becomes decadent, outlawed, and Western (once more). Cui Jian's use of the trumpet, is at once an appropriation of an 'official', and so 'Chinese', instrument, and a re-appropriation of a Western instrument.

Also exploiting the national heritage is a group whose very name lays claim to the Chinese tradition: Tang Dynasty. Their recent made-for-MTV video makes use of a sort of Orientalist dream sequence of an abandoned, perhaps Tang, temple, Buddha, and even earlier ruins situated somewhere on the periphery. As in the Hei Bao videos the band itself is seen performing both in the studio (in typical masculinist heavy metal poses), and on location. Whilst the past supplies the props, the video production technique is standard for the 'postmodern' modernist video: we never know why certain things happen, or even precisely what is happening. We are forced to exist in a non-rational, haphazard universe where we cannot expect any 'closure' of the ordinary kind (Kaplan 1987, p. 63). The other video technique this video adopts is also typical of 1980s heavy metal videos, in which the bands are depicted in the studio exuding a hectic vitality. Thus we cut between the known and knowable heavy metal band in classic pose, and an incoherent narrative 'undercut by pastiche' in which 'signifying is undercut by images that do not line up in a coherent chain' (ibid.). But this video cannot resist having some of the images communicate an almost clear signifier. There are a number of large red flags displayed falling to the ground throughout the video, and at the end of the video limply hanging on piles in a half-lit interior, thus connecting the crumbling traditional signs of the past to the fading signs of the official present.

While the Chinese Communist Party, like other official communist parties, has consistently employed nationalism to garner political support, the recent statesponsored marketing of the Party-State heritage (Mao memorabilia, Maoist discobeat musical eulogies and so on) seems innovative. But, in fact, the Chinese Communist Party and other vanguardist intellectuals from the end of the nineteenth century onwards have appropriated and redeployed popularly consumed culture. In the 1930s, cultural worker-soldiers were dispatched from Ya'an to collect folk songs, minge, which were subsequently adapted for the purposes of revolutionary propaganda; a process which - and this is illustrated by the now classic contemporary Chinese film Yellow Earth by director Chen Kaige - often stripped the songs 
of their original subversive meaning. As for the contemporary Chinese official use of mechanically and electronically produced music, it is the logical outcome of a non-modern state in the process of modernisation.

Nationalism is invested in the modernisation like all other resources, like poetry, like pop lyrics. Alain Touraine describes nationalism as the 'mobilization' of the past and of tradition in the service of the future and of modernity. As to the function of 'the nation', Touraine sees the nation not as 'the political face of modernity, but rather as 'the principal actor of modernization, which is to say it is the non-modern actor which creates a modernity in which it will try to maintain control at the same time as accepting to lose it in part to the benefit of internationalized production and consumption' (1992, p. 161).

In China, the oppositional Cui Jian speaks from within a patriotic discourse which, in its modern manifestation, dates back to the end of the nineteenth century when poet, intellectual, and political actor were constructed as a unitary subject. It was a discourse reinvented and reinvigorated by the patriotic intellectual and cultural movement of 1919 known as the May Fourth Movement, and, with its dual appeal of modernisation and national (re)assertion, it has proven an indispensable discourse of power ever since. While he engages in critique of capitalist consumption and looks to an ideal which is somehow more spiritual, he nevertheless sees salvation only in some sort of overhauled nationalism.

If, as Attali tells us, 'music . . . is present in myths', it is also the case that 'myths' are present in music, whether those myths be nationalist, sub-nationalist, or Utopian.

\section{IV}

I should now like to turn to the question of hybridity. While hybridity necessarily always bears the imprint of cultural dominance, it is today a fact of social reality for many parts of the world and the dominance and cultural imperialism inherent in it does not prevent the subversive and progressive being produced out of, and through it (Chow, forthcoming). At a recent international writers' forum focused on the Middle East which tackled questions of identity and questions of 'authenticity in borrowed Western form' and language, Edward Said spoke of accepting 'the reality of hybridity', given that now 'we are all mongrels'.

Homi Bhabba (1985) has thought through hybridity in a specific colonial context, that of British colonialism, viewed historically and geographically in an effort to describe the conditions of colonial discourse. Interestingly, Bhabha's description of the effect of English colonial power seems to me easily capable of describing, in a substantially different context and period, the effect of the power of contemporary China's dominant structures of power, and the reception and subversion of regnant power by popular culture. We have to imagine for this purpose Chinese official power over the last three or four decades as being dynamic, rather than static, and as already itself being a hybrid form of power, a 'con-fusion', or rather a product, of Marxist-Leninist and Chinese imperial-Confucian ideologies. A type of power emerges which relies on old and new patriotisms, indigenous, traditional, and Western nationalisms. It has been a power that has battled with the contradiction of the cultural contamination implicit in the process of modernisation. But it has been only during the last few years that the pursuit of consumer- 
ism as a means of modernisation has clashed with the contradictory desire to retain centralised state/party power over cultural consumption.

Bhabha wonders, referring to Steven Lukes' argument, if 'the acceptance of authority excludes any evaluation of the content of an utterance', and if the course of authority 'disavows both conflicting reasons and personal judgment, then can the "signs" or "marks" of authority be anything more than "empty" presences of strategic devices? Need they be any the less effective because of that? Not less effective but effective in a different form, would be the answer' (ibid. p. 155). Here, I think of the redeployment of national(ist) and party signs by the likes of Cui Jian.

Going on to consider what he sees as Tom Nairn's revelation of 'ambivalence between the symbols of English imperialism', Bhabba concludes that the 'production of hybridity . . . no longer simply commands authority. It gives rise to a series of questions of authority' (ibid.).

In the contemporary Chinese context, I am suggesting we have various levels and forms of hybridity. There is, of course, the already hybrid, dominant discourse of power exercised by the Party-State, official society. Then, there is the hybridity of the reaction of the dominated that emerges in the appropriation and redeployment of 'signs' of Chinese State and Party power - the red flag, the Great Wall, the red kerchief of the Red guard and young pioneer, the Forbidden City, the sinified once-Western trumpet used by pop musician Cui Jian, the image of Chairman Mao. Chairman Mao now seems as universal a signifier as Madonna, but with multiple semiotic readings. Pasted to a mainland Chinese bus driver's window or hanging from a cab driver's rear-view mirror, Mao is a talisman to protect against misfortune; held up by students at a pop concert Mao is a symbolic icon, perhaps not even ironically deployed, reminding the authorities of forsaken ideals. Both dynamic and historically specific, we may perceive in such redeployment an estrangement of the familiar symbols of Chinese "'national" authority" and in the appropriation of such symbols the dominated, unofficial society's 'sign of its difference'.

The problem of authenticity and cultural hybridity has dogged modern China's culture(s) for a century at least. Chinese 'new poetry', a vernacular poetry which twice, in the 1920s and 1930s and again in the 1970s and 1980s, mimicked extensively modern European poetry before settling into a stable hybridity, has been received unsympathetically by Chinese traditionalist and Western sinologist alike. And yet the modern communist orthodoxy, sometimes with great reluctance - Mao was no lover of new poetry - has appropriated and sought to use new poetry as much as any other form regardless of its foreignness. As with 'new poetry' so with the pop song, as with the fin de siècle reformism so with capitalistnationalism, as with Maoist Marxism-Leninism, so with Dengist authoritarian consumerist capitalism. There has, however, always been more anxiety over reproducing the modern poem than reproducing television sets or bicycles, which are perhaps more concrete forms of the legacy of foreign imperialist dominance, of cultural imperialism. Here, I should emphasise that just as I wish to avoid representing popular culture as somehow less worthy of serious attention than 'high cultural' forms, neither do I intend to romanticise pre-consumerist Chinese culture.

Yet, the cultural, the aesthetic, sphere has always been a space where cultures in the process of modernisation have attempted to protect the cultural tradi- 
tion. But, in fact, traditional culture, literature, folk art, cuisine, the way of life, have not simply been protected as a sacred, but rather pushed into service as part of the patriotic rationale for modernisation:

Germany and Italy like Japan, and after them numerous other countries, have associated modernization with the safeguarding or restoration of a national culture, for, faced with a modernity identified with British commerce or the French language, how could a nation State do otherwise, in the defence of its independence, than to mobilize non-modern resources, be they cultural, social or economic? (Touraine 1992, pp. 161-2)

Touraine sees this trend as having continued until the modernisation of the Islamic states where 'the theme of national cultural renaissance has come into conflict with traditionalism as much as with liberal modernity' (ibid. p. 162). In China over the last century the regnant authority, Communist or otherwise, which has taken charge of the patriotic project of national salvation, deeply enmeshed in the project of modernisation, has wavered over this very problem of safeguarding the national culture. The spectre of non-Chinese theory and praxis hovers over modern China, and the result of the confrontation with Western capitalist imperialism and its counter-ideology is to be found in Chinese hybridity. Hybridity contests, challenges, weakens and ultimately invalidates the authority and legitimacy of dominant monolithic, national cultures; this is a process happening now in Britain, America and elsewhere in the advanced capitalist societies, 'Hybridity intervenes in the exercise of authority not merely to indicate the impossibility of its identity but to represent the unpredictability of its presence' (Bhabha 1985, pp. 156-7). Thus, as Rey Chow has shown, Hong Kong's hybrid culture indicates the 'impossibility' of China's identity (Chow, forthcoming).

The dominative practices and the subversive practices which the oppressed have to negotiate are indeed still extant. It is surely true to say of Chinese pop groups, whether on the mainland or in Hong Kong, that their appropriation both of present and past national 'official' culture into a 'foreign' process of mediation, is a 'display of hybridity', a 'peculiar replication' which deeply disturbs Chinese regnant authority (Bhabba 1985, p. 157).

What is certain, however, is that the noise of late twentieth-century popular lyrics, in particular rock songs, can disturb the State. But given the historical and cultural context of the Chinese song lyric it is perhaps less surprising; for since the orality of popular song was appropriated by the State and made literary in the Shijing or Book of Songs over two thousand years ago, lyrics have consistently been interpreted politically, and authority has always been aware of their subversive potential.

In the Chinese context, not only contemporary Chinese poetic production, but also the interventionist production of musicians and lyricists like Luo Dayou's Music Factory in Hong Kong social life, show that not merely can one, as the French feminist critic Hélène Cixous - who reads lyric discourse as critically and subversively effective - has put it, 'remain poetic in the very midst of history', but that one can remain historical, or even take it upon oneself to establish historicity, in the very midst of poetry (Cixous 1991, p. 111). Perhaps it is precisely this attribute that makes it 'more dangerous'. Cixous, however, might balk at an 'intersection' between popular music and history, which we have seen in Hong Kong and China in the last decade, since it is precisely in the 'slowness . . . thought and silence' of the Russian poet Marina Tsvetayeva's poetry that she sees a refuge from the 'noise machines' of modernity whose values are 'oriented by speculation, 
money, and profit' (ibid, pp. 111-2). For Cixous, Tsvetayeva's poetry constitutes quiet redistance not merely against live under Stalinism but against capitalist modernity. What we have in the recent Chinese context in addition to the undoubted 'speculation, money and profit' associated with the 'noise machines' (video and karaoke machines) of the music industry, is far from quiet but is still resistant to a neo-Stalinist Chinese State, and perhaps resistant also to the materialism of capitalist modernity now found on both sides of the China-Hong Kong boundary.

But now in Chinese as elsewhere, poetry, which was for so long song, has been given back its voice. It is once again loud noise. That the State in China has increasing difficulty in controlling the broadcasting and distribution of unlicensed cultural products becomes daily more obvious, and the poetry of the contemporary technological world empowered by noise insists on being heard. 'If the state keeps itself in line ... through the linear, empty space of homogeneity, then poetry worries this place or time with heterogeneous performance. If the state is a place of reading the lines correctly, then poetry is the site of audition, of embodied sounding on state wrongs' claims Houston Baker, alluding to Benedict Anderson's theory (Baker 1991, p. 205). Baker, in this supposedly 'post-poetry' world, easily elides distinctions between poetry lyrics and popular lyrics, talking of American idols like Chuck Berry as 'people's poets' (ibid, p. 205). Unlike Cixous, Baker has no problems with loud noise; the loudness of popular music fits easily into his reading of lyrical discourse; a reading which accommodates both poetry and rap alike. Learning from Stallybrass and Bhabha that 'nationalist and postrevolutionary discourse is always a discourse of the split subject', Baker concludes that in order to 'construct the nation, it is necessary to preserve a homogeneity of remembrance (such as anthems, waving flags, and unifying slogans) in conjunction with an amnesia of heterogeneity' (ibid., p. 206). Baker thus sees poetry again 'like rap, as an audible or sounding space of opposition' (ibid.). He is not, after all, so very far from Cixous.

Cui Jian turns the tropes and signs of remembrance back on the State, to recall what the State wants to forget, but he also redeploys them in his own patriotic project which aims to save China from the new materialism through the consumerist culture of popular music that he calls the 'Long March of Rock and Roll'. The question becomes: is the deconstruction of one totalising practice not bound to lead to another? Historical hybridised cultural traditions are necessarily hidden and suppressed by the modern State whose traditions have to be monocultural. Can any culture based on a 'patrie' however marginalised, however worthy, be tolerant and fail to have totalising ambition?

While Hobsbawm clearly accepts that French as a national language was foisted on the inhabitants of the space called 'France' by the regnant authority, he nevertheless still sees the 'nation' as a serviceable vehicle on the road to a more progressive society. Alain Touraine conversely sees a correspondence between 'modernity and the nation, either in its colonial form, or in its nationalist form, which has destructive effects', whilst the dissociation of economic modernity and national consciousness seems to Touraine to be 'one of the important aspects of the fragmentation of the classic idea of modernity and of conceptions of modernisation which consider industrialization, democratization and the formation of national States as three interdependent aspects of the same general process', an idea which ought to be 'more and more forcefully rejected' (Touraine 1992, p. 165). 
Can there be a 'patriotism' which will not become a nationalism deployed as an 'instrument in the service of the modernizing, authoritarian and nationalist State which in calling on the artificially reconstructed idea of a Volk' in the worst case creates 'a totalitarian power in the name of Ein Volk, Ein Reich, Ein Führer', (ibid.); an instrumentality which as we have seen again recently in ex-Yugoslavia is not restricted to large states. Touraine would certainly see the possibility of such a dissociation in the 'fragmentation of classic modernity'; 'It is . . . the increasing separation of the supposed attributes of rationalization, itself identified with modernity, which best corresponds to today's world' (ibid).

I should like now to deal with effectiveness of music as a tool of subversion. In the Chinese context, should those who constitute the regnant authority in China be concerned by the subversive potential of mechanically and electronically reproduced music? It may well be that the creator and producer of Beijing Reggae, a Chinese American, takes pleasure in bringing Afro-Caribbean musical expression into electronically reproduced Chinese popular music. He may believe he is doing something novel, even progressive, but he does it with the full and open cooperation of Chinese Communist officials in charge of the music industry. Moreover, the product again is intended mainly for Hong Kong and overseas distribution and consumption. In producing reggae and rhythm and blues cover versions of revolutionary classics, is he not negating the ironic and subversive potential in what should be the very moment of subversion?

From time to time, Cui Jian's concerts have been banned, while Hong Kong performers are allowed to perform in the Peoples Republic of China. While their popularity rests on a mild critique of Chinese Communist Party-dominated society, there is a sense that they will not push that critique too far for fear of losing access and, of course, profits. Cui Jian and other musicians and lyricists with similar mentalities are still the minority in the music business and they are after all subject to the constraints of that business. Moreover, concerts of all types are, nevertheless, comparatively few, while what Attali terms 'the individualized use of order', for instance, the Walkman, and increasingly the karaoke machine, is widespread and continuously available (Attali 1977, p. 100) ${ }^{7}$. But while initially Western pop music and Western-Chinese pop music may appear, and even be, subversive and run counter to the official musical order of the Maoist period, ultimately the availability, facilitated by consumer capitalism, of stockpiled sociality, itself may repress people (Williams and Hirschop 1989). As Williams and Hirschop have it, in their critique of Attali, 'a medium established to cement sociality now provides desires, interests and a sense of identity at such a deep level that public occasions [such as pop concerts, but one might also include "official" music concerts, live, or broadcast recorded, of "revolutionary" or officially sanctioned music] are no longer necessary to "cement" anything'. Or as they add, glossing Attali, 'once conformist personal desires can be manufactured, repression becomes unnecessary as peoples repress themselves' (ibid., p. 469).

According to this logic even the remarketed, remixed and repopularised Maoist revolutionary songs are unnecessary to effect the desired repression, in which case the function of the marketing of such music would be simply profit- 
making and fulfilling pre-existent desires. This is a somewhat totalised view of the consumption of popular music, akin to a belief in the total efficacy of a dominant ideology, a thesis that has been modified, if not overturned, over the last decade or so by the work of Abercrombie, Hill and Turner who

reversed the contention and argued that ideology does have significant effects but these are primarily on the dominant rather than the subordinate class. What has been important for the stability of capitalism is the coherence of the dominant class itself, and ideology has played a major role in securing this (Hill 1990, p. 2).

However, while finding their argument attractive, I would contend that the ruling authority's domination of society is secured by a variety of means, namely economic imperatives, the partial success of ideological control, and the threat or use of force.

The criticism levelled at what is seen as Western-style, popular culture by the Chinese Communist Party ideological purists, the 'conservatives' in the leadership focuses on its capacity to (re)produce 'bourgeois individualism'. They want a modernised economy without a bourgeois individualist mentality developing. According to Hill there is no reason why they cannot have their cake and eat it, since he concludes 'that individualism and capitalism have no necessary or enduring relation: any linkage is entirely contingent'. We should not, therefore impatiently await the collapse of the Chinese Communist Party-capitalist Chinese state simply because new cultural forms and phenomena have appeared in the public sphere. Hill goes on to explain

Individualism did give capitalism a particular shape in America and Britain, notably in the early capitalist period, and capitalism in turn shaped individualism by emphasizing its positive features. However, oriental capitalism and late capitalism in the west bears no particular relation to individualism; indeed they flourish best in the absence of an individualistic culture. While collectivism may be an appropriate cultural milieu for capitalism, individualism now degenerates into the culture of individuality, which has little economic effect. We conclude that the capitalist form of economic organization has no need of the bourgeois cultural form of individualism. Indeed, on theoretical grounds, we find that capitalism has no necessary ideological requirements at all. (ibid, p. 5)

No wonder Hong Kong big business is happy with Chinese Communist plans for the colony. The ideology, the prevalent false consciousness, of the moment is that market capitalism, a loosening of economic controls, the opening up to the world (markets), will somehow naturally lead to a more 'democratic' society with enforceable human rights; in other words that amelioration will come about in non-material as well as material conditions. This is a mentality dominant both in non-Chinese and Chinese analysts of China; it is, for instance, the ideology that permeates the narrative of the then controversial 1980s television series 'River Elegy'. It is surely clear to all at the end of the twentieth century that there is no organic link between capitalism and democracy. Whether or not individual interests 'are better served by individual rather than collective strategies', it is the lack of any obvious nexus between materialist progress and a more altruistic vision for society that emerges strongly in Cui Jian's discourse (ibid., p. 26). ${ }^{8}$ Pertinently, Hill admits that 'while instrumentalist is an important dimension of values, there is also a strand of altruism and principled commitment in popular culture' (ibid., p. 25). ${ }^{9}$

But while the linkage between individualism and capitalism may not be essential to profit-making, surely the marketing of the ideology of individualism 
is essential to the extension of the music industry. In any case, although the 'individual' may believe that while engaged in solitary consumption of music they are either indulging a private or personal taste, or rather participating in some larger collective or network of use - whether or not the music is resistant or engaged in critique - the result is an effective and necessarily unperceived alienation.

\section{VI}

My personal inclination is to privilege the periphery against the centre. There is, however, a danger in privileging the marginalised, the periphery, of abandoning the centre and the centre-controlled; a centre whose regnant authority still dominates the lives of many who, while in a sense marginalised, are hierarchically, vertically dominated in a more traditionally conceived way. This is why it is difficult to discount comprehensively the practice of those whose work lies within a more traditional discursive framework yet addresses the hierarchical inequalities of capitalist society, which have not gone away simply because there are more attractive and often less complex issues to work with. It also provides the reason why, while Luo Dayou and his Music Factory have a much more attractive project of subversion and critique, despite Cui Jian's naive patriotic and anti-materialist sentiments, his sound-challenge at least maintains an oppositional discourse on the mainland that other voices may yet develop. The noise of opposition (whether in colonial and soon-to-be recolonised Hong Kong, or on the Chinese mainland, whether in Toulouse, or in France as a whole) is essential, for noise 'enables a social occupation of space, and the political establishment of forces within a demarcated area' (Socherty 1990, p. 11).

In China, Hong Kong and elsewhere, there is naturally no reason to suppose that popular music in the late capitalist era will not continue to function so as to maintain dominant forces around the globe, whether in China and other parts of the region, or wherever popular music is consumed. But the dominance of 'official' media will not prevent the voices of subversive, trouble-making, troubadours from disturbing the imposed order of official noise.

\section{Endnotes}

1 Cited in South China Morning Post Weekly, 1,33, 5-6 December 1992, p. 6.

2 With the assistance of George Simpson. The chapter on popular or 'light' music in the later Sociology of Music is substantially similar to the article written with Simpson and relies on the same research, in other words both refer to the production and consumption of popular music in the USA of the late 1930s.

3 See especially pp. 85-100; see also O'Sullivan et al. 1983 , pp. 18-20.

4 More strictly speaking direct broadcasting by satellite (DBS) directly to the point of consumption, the household.

5 An English translation of Attali (1977) is published by the University of Minnesota Press
(Theory and History of Literature, Volume 16). For the purposes of this article I have used my own translations.

6 Alain Touraine (1992) observes that 'nothing authorizes the identification of modernity with a particular mode of modernization, the capitalist model, which defines itself by this extreme autonomy of economic action. From France to Germany and from Japan or Italy to Turkey, to Brazil or to India, historical experience has shown, on the contrary, the almost universal role of the State in modernization . . . Outside a few centers of the capitalist system, modernization has been carried out in a more coordinated and authoritarian manner' (p. 237). 
7 See also Rey Chow (1991), in which she discusses in detail the difference that the Walkman has made to music consumption. In particular she observes that the 'form of listening that is a decisive break from the past is that made possible by the Walkman' (p. 144).
8 See also Cui Jian's statements in 'China rocks: the long march of Cui Jian', Rhythms of the World, Penumbra, BBC2, 16 February 1991. BBC TV interview passim.

9 Hill is here drawing on J. Rentoul (1989).

\section{References}

Adorno, T. W. 1941. 'On popular music', with the assistance of George Simpson, Studies in Philosophy and Social Science, 11/1, pp. 17-48

Attali, J. 1977. Bruits: essai sur l'economie politique de la musique (Paris)

Baker, H. A. 1991. 'Hybridity, the rap race, and pedagogy for the 1990s', in Technoculture, ed. C. Penley and A. Ross (Minneapolis)

Bhabha, H. 1985. 'Signs taken for wonders: questions of ambivalence and authority under a tree outside Delhi, May 1817', Critical Inquiry, 12, autumn, pp. 144-65

Cixous, H. 1991. Readings: The Poetics of Blanchart, Joyce, Kafka, Kleist, Lispector and Tsvetayeva. Trans. and ed. Verena Conley (Minneapolis)

Docherty, T. 1990. After Theory: Postmodernism/Postmarxism (New York)

Fiske, J. and Hartley, J. 1978. Reading Television. (London)

Hennion, A. 1983. 'The production of success', Popular Music 3, pp. 159-93

Hills, S. 1990. 'Britain: the dominant ideology thesis after a decade', in Dominant Ideologies, ed. N. Abercrombie, S. Hill and B.S. Turner (Winchester)

Kaplan, E. A. 1987, Rocking Around the Clock: Music Television, Postmodernism, and Consumer Culture (New York)

O'Sullivan, T. et al. 1983. Key Concepts in Communication (London)

Rentoul, J. 1989. Me and Mine: The Triumph of the New Individualism? (Winchester)

Rey Chow, 1991. 'Listening otherwise, music miniaturized: a different type of question about revolution', Discourses, 13/1, pp.

Forthcoming. Diaspora,

The Story of Hua Guan Suo. 1989. Trans. and ed. Gail Oman King (Tucson)

Touraine, A. 1992. Critique de la modernite (Paris)

Williams, A. \& Hirschop, K. 1989. Review of Noise, by J. Attali, Textual Practice 3/3, pp. 462-472 